\title{
Meeting the Enemy in World War I Poetry: Cognitive Dissonance as a Vehicle for Theme
}

\author{
David Poynor $\mathbb{D}$
}

English Department, United States Naval Academy, Annapolis, MD 21402, USA; davidpoynor@gmail.com

Received: 28 January 2019; Accepted: 13 February 2019; Published: 19 February 2019

\begin{abstract}
Some World War I poems show an enemy soldier up close. This choice usually proves very effective for expressing the general irony of war, to be sure. However, I submit that showing interaction with the enemy also allows the speaker space to wrestle with internal conflict, guilt, or cognitive dissonance, and that it allows-or even forces-readers to participate in that struggle along with the speaker. While the poets' writings no doubt had therapeutic effects for the poets themselves, I focus more on the literary effects, specifically arguing that the poems are powerful to us readers since they heighten the personal exposure of the poets' psyches and since they make us share the dissonance as readers. I consider poems by Siegfried Sassoon, Wilfred Owen, Robert Graves, Ford Madox Ford, Herbert Read, and Robert Service.
\end{abstract}

Keywords: World War I; war poetry; cognitive dissonance; enemies; encounters; Siegfried Sassoon; Wilfred Owen; Robert Graves; Ford Madox Ford; Herbert Read; Robert Service

The canon of Great War English-language poetry, taken as a whole, is often said to reflect the absurdity and horror and all-encompassing haunting nature of war, and a rather salient theme is the common humanity and victimhood of those on both sides. Certainly there are some poems that speak nationalistically or otherwise derogatorily towards the German aggressors (Kipling 1914, "For All We Have and Are"; 1918, "Justice"; Hardy 1915, "The Pity of It"). But these poems typically refer to the enemy at a rather abstract level. Overall the role of the enemy in World War I poetry-especially by the poets who directly participated in combat-seems to be that of co-victim of a grander evil that afflicts both sides.

In some poems the poets have chosen to show an enemy soldier up close. This choice proves to be particularly effective for expressing the general irony of war, to be sure. But I submit that this approach also allows the speaker space to wrestle with internal conflict, guilt, or cognitive dissonance. Furthermore, the heightened personal exposure-the rawness or vulnerability or authenticity—of the poets' psyches is likely what gives the poems their power, since it demands that the reader participate in the struggle.

The gist of the concept of cognitive dissonance is that when people hold one belief, but find themselves behaving contrarily to that belief, they are in a state of internal discord as to which is true: their belief they said they held, or the behavior they seem to be actually doing. The theory, originally posited by Festinger in the late 1950s (Festinger 1957; Festinger and Carlsmith 1959), suggests that people must come up with some way to resolve the internal dissonance, so they tell themselves either that they did not actually believe so strongly what they had said they believed, or that they did not 
actually do [much of] what they seemed to be doing, or some other psychological ploy. ${ }^{1,2}$ Though much has been made of the scientific testability of Festinger's ideas (See Krause 1972, for example), the essence of Festinger's original conception is that cognitive dissonance causes psychological discomfort and therefore is "a fundamentally motivational state" (Elliot and Devine 1994). This is the sense with which I am most concerned. I am focusing on the idea of internal discord and its effects-which might include madness if it is not mitigated, or telling a story in a way that eases the internal discomfort, or specifically discussing serious mental illness as a way to assure oneself that one is not so far gone.

Frontline soldiers would seem to be particularly susceptible to unresolved cognitive dissonance due to the extreme nature of what they are asked to do and see. For example, perhaps they have been told to be courageous, and they likely consider themselves to be so; but in a battle they find themselves cowering in a shell crater rather than advancing toward the enemy. The soldier could decide he is actually a coward after all (thus his initial belief was wrong), or he could decide the behavior was not cowardice but perfectly natural (thus his behavior was not what it seemed). The first option, identifying oneself as a coward, has a host of other social and internal drawbacks. But the second option may not satisfy either since it is somewhat dishonest to oneself. Such is the dilemma. ${ }^{3}$

Daniel Hipp's book The Poetry of Shell Shock (2005) discusses Great War poets Wilfred Owen, Ivor Gurney, and Siegfried Sassoon, putting their creative output in the context of their psychological injuries and recoveries, and arguing that the poems were deliberate and effective therapy (Hipp 2005, pp. 15-43, 44-107). Hipp also traces the developments in the understanding and treatment of "shell shock" in general and points out several theories of the time (ibid. pp. 15-43, 44-107) ${ }^{4}$ Hipp's discussions highlight the therapeutic effects of the poets' writings for the poets themselves, but I will focus more on the literary effects, specifically arguing that the poems are powerful to us readers since we are made to share in the dissonance.

Michael Sarnowski, in a recent article in this journal, argues that the most salient and poignant war poems that speak of encounters with the enemy are those that "[shorten] the distance between the realities of ... War and the reader" (Sarnowski 2018, p. 7). For the World War I poets who experienced physical contact with the enemy, Sarnowski suggests, the tangible closeness of the two combatants contributes to the shocking effect, whereas World War II poet-soldiers who did their killing from a distance had to express this same humanization of the enemy in somewhat different ways. Sarnowski's

1 See Festinger 1957, in which he lays out his theory. And the watershed experiment is that of Festinger and Carlsmith 1959, in which subjects were asked to do a task they all thought to be boring (the belief) but to tell the next person that it was fun (the inconsistent action). They were paid either $\$ 1$ or $\$ 20$ to do so. In the $\$ 20$ condition the money explained the seeming discrepancy between the original belief and the inconsistent action, and these subjects showed little cognitive dissonance. The subjects in the $\$ 1$ condition, though, could not say that the money was the reason for their behavior, so they had increased dissonance; and they sought to resolve it by changing their original attitudes to match their behavior.

2 The original concept as posited by Festinger and his colleagues is usually spoken of in the context of people changing their minds about something. But more recently the concept has been broadened a good deal. For a good accessible summary of the concept, see McLeod 2018.

McLeod offers this critique: “Is it a perception (as 'cognitive' suggests), or a feeling, or a feeling about a perception? Aronson's revision of the idea of dissonance as an inconsistency between a person's self-concept and a cognition about their behavior makes it seem likely that dissonance is really nothing more than guilt" (McLeod 2018, p. 5). For the purposes of this paper, this reinterpretation will suffice.

3 Indeed the concept of cognitive dissonance has been applied repeatedly in the context of war. As a single recent example, see Wayne Klug et al. 2011.

4 Hipp paraphrases MacCurdy's (1918) treatise War Neuroses which suggests that because of the nature of trench warfare, "The First World War denied the soldier's acting in accordance with either a peace or war mentality—he could be neither compassionate nor aggressive toward the enemy. Instead, the instinct for survival became foremost in the soldier's mind" (Hipp 2005, p. 22) and again, "The soldier was forced into a prolonged state of waiting, unable to act in any manner other than a defensive posture" (Hipp 2005, p. 22). Freud, of course, would seem to factor in here as well. Freud's explanation was that "The conflict takes place between the old ego of peace time and the new war-ego of the soldier" (quoted in Hipp 2005, p. 26). Indeed, the War brought legitimacy to a Freudian understanding of war neurosis as "a flight from an intolerable, destructive reality through illness" (Leed 1979, quoted in Hipp 2005, p. 25).

For the purposes of this paper, I am not concerned with differentiating Festinger's "cognitive dissonance" from Freud's concept of an internal "ego-conflict" or from MacCurdy's idea of a struggle between conflicting "mentalities," and I even use the terms somewhat interchangeably, since they express the same essential idea. 
argument focuses on distance-especially the difference between the combatants' distance in the two Wars' poetry. He suggests that the close distance "makes readers complicit in the actions of war ... [and exposes] readers to the battlefield experience and the degrees of inner turmoil of soldiers" (Sarnowski 2018, p. 7). With regard to the World War I poets, Sarnowski's point is well-taken; there is something exceptionally powerful about the poems that deal with direct interaction with the dead, especially the enemy dead. His discussion of Owen's "Strange Meeting" is also particularly helpful. It is at the end of his paper that Sarnowski briefly touches on the speaker's "inner turmoil" and the importance of that being shared by the reader. This shared internal dissonance is where I want to focus my attention.

Jahan Ramazani's 2016 article in Modernism/modernity also discusses how various Great War poets have used the trope of interaction with the enemy in one form or another to conceive of the enemy as "one's kin or mirror image," to "[break] down the narcissism of minor differences and [rhyme] soldiers across national lines," and to "dissolve any notion of one nation's higher claim to honor, freedom, justice, righteousness, and poetry by showing the opposing soldiers to be, in Service's words, 'just the same'"(Ramazani 2016, p. 871). Ramazani's paper is focused on the Great War, and it provides excellent discussion of examples of Great War poems that further a grand theme of "cosmopolitan sympathies," a phrase Ramazani borrows from Isaac Rosenberg's poem "Break of Day in the Trenches".

Ramazani and Sarnowski both show that this theme of common humanity is conveyed especially powerfully in poems that depict a soldier seeing his enemy face-to-face. I submit that one reason this trope is so effective is that it allows—or even forces—readers to vicariously participate in the speaker's internal dissonance.

\section{Scope and Method}

There are not very many poems in the entire canon that actually show a direct face-to-face encounter with an enemy soldier. For this study I examined the entire contents of Tim Kendall's (2013), Candace Ward's (1997), and Jon Silkin's (1996) excellent anthologies and also the entire collection of Sassoon's war poetry as collected by Rupert Hart-Davis (Sassoon 1983), and Owen's war poetry as collected by C. Day Lewis (Owen 1964) and Jon Stallworthy (1974). Many of the poems convey the horrors of the War, and some of them mention dead soldiers, but only a few poems deal with encountering an enemy, alive or dead, up close.

My initial approach was to categorize Sassoon's war poems (Sassoon 1983) into four groups. There are poems with a specific depiction of enemies, usually dead, of which there are only possibly four. In a second group are poems that specifically and concretely depict a dead fellow English soldier, known or unknown, of which I count 11 for sure and four more that likely fit here best, so 15 in total. A third category is of poems that deal with or mention death or the dead in a less specific or more abstract way, not directly describing the event; in this category I put 38 or 40 poems. The final category is poems that do not deal with death at all (though they may deal with the abysmal fighting conditions or maybe with abstract sadness or longing). In this category are 46 poems written before 1920 and five written after.

A similar catalog for Wilfred Owen's war poems (Owen 1964) yields a similar pattern. Poems in which the speaker directly meets the enemy are very few, only one ("Strange Meeting") or at most three, depending on how they are interpreted. Poems in which the speaker describes dead English fellow soldiers count 10 or 12 . Poems that deal with the dead in a less direct way count 19. Poems that do not specifically mention death at all number 21.

5 Ramazani offers this important qualifier: “Of course the poetic cosmopolitanism I've been tracing isn't without its limitations. These cross-national solidarities may have global reverberations but are still largely enacted within a European and North American sphere. None of these poems aspire to solidarities with, say, a Turkish soldier in the Ottoman army. Despite the African, Middle Eastern, South Asian, and other non-European involvements with the war, our published poetic archive is largely European" (Ramazani 2016, p. 869). 
Finally, beyond Sassoon and Owen, I count only four that mention encountering the enemy, and which I will discuss in this paper: "Only a Boche" by Robert Service, "That Exploit of Yours" by Ford Madox Ford, "A Dead Boche" by Robert Graves, and "The Happy Warrior" by Herbert Read.

But even among those poems that seem to mention an enemy, there are different levels of intimacy and interaction. Therefore, in this paper I have organized the poems according to the following three categories: poems that depict conversation or intimate interaction with an enemy, poems that depict only the seeing or touching of an enemy, and poems that are unclear about whether the encounter is with an enemy or not. Within those categories I have kept Sassoon's together and Owen's together but without regard to dates.

Whereas other scholars have so capably put the various poets' works into the context of the poets' lives and personal development (see Hibberd 1986, 2003; Stallworthy 1974; Campbell 1999), I have chosen to address the works more as individual pieces of art that all share a common focal point and possibly common themes and techniques. Where necessary I have considered the particular history or situation of the poet, but overall I wanted to examine the poems by type. I will not provide a complete explication for each poem, but will focus on the aspects that are germane to the discussion.

So, let us consider those few poems-four by Siegfried Sassoon, three by Wilfred Owen, one each by Robert Graves, Robert Service, Ford Madox Ford, and Herbert Read—in which the enemy soldier is an actor or foregrounded presence.

\section{Poems Depicting Intimate Interaction or Conversation with the Enemy}

\section{1. "Only a Boche" by Robert Service (1916)}

The first poem I want to consider is Robert Service's "Only a Boche" (Service 1916). ${ }^{6}$ This poem portrays one of the most extended dealings with a direct face-to-face encounter with the enemy. In this poem the enemy soldier is alive-though barely-at least for a while. The poem's speaker is presumably Service himself (who was an ambulance driver) or someone like him serving in a medical capacity, not as a combatant. This noncombatant speaker marks an important difference from all the others under consideration. Nevertheless, the poet-speaker makes it clear that he is on one side and the Boche is on the other. In the poem, the medical team take in a gravely injured German soldier who apparently dies despite their best efforts, and who lies on his pitiful deathbed in a room where the ambulance-men play cards.

Throughout the poem, the speaker refers to the enemy soldier in a cold, even insulting way: "Only a Boche" (title, lines 24, 47), "What's the use of risking one's skin for a tyke that's going to die?" (line 2), "the cursed foe" (line 16), "confound him" (line 31), and "One foe the less" (line 49). But it is clear those words are bluster, or else they are an ego defense mechanism for dealing with cognitive dissonance, for the speaker's behavior belies his bravado. Despite the Boche's status as an enemy, the speaker takes him in and treats him (lines 1-12), admires his toughness (line 7), and even "carrie[s] him in like our own" (line 8). The dying man is allowed to stay in the presence of the card-players (lines 9-18), and in a break in the card game the speaker goes to the man and observes him closely. During this perusal, Service's speaker notices that "The dying Boche on the stretcher there has a queer resemblance to me" (line 24). This is the central theme of the poem. The speaker goes on:

It gives one kind of a turn, you know, to come on a thing like that.

It's just as if I were lying there, with a turban of blood for a hat,

Lying there in a coat grey-green instead of a coat grey-blue,

With one of my eyes all shot away, and my brain half tumbling through; (lines 25-28)

6 See Ramazani's (2016) excellent discussion of this poem. Ramazani says, "Although Service has received less literary critical attention than other war poets, 'Only a Boche' and 'A Song of the Sandbags' are vivid dramatizations of a soldier's tentative breakthrough to the shared humanity of the enemy other" (p. 864). I do not discuss "A Song of the Sandbags" in this paper; while it certainly speaks about the men's shared humanity, it does not involve actual meeting of an enemy. 
And confound him, too! He wears like me on his finger a wedding ring,

And around his neck, as around my own, by a greasy bit of string,

A locket hangs with a woman's face, and I turn it about to see:

Just as I thought ... on the other side the faces of children three; (lines 31-34)

'Zut!' I say. 'He has beaten me; for me, I have only two,'

And I push the locket beneath his shirt, feeling a little blue. (lines 37-38)

The speaker mentions the contrasts between himself and the German: they wear different color coats and have a different number of children, for example. But ironically, the dying German is noteworthy primarily for his similarity to the speaker himself. The close contact with the dying man has taught a lesson to the speaker and the reader about the common humanity of those on both sides. The speaker knows that the German man's family, so similar to his own, will experience the same anguish as any other family would. The idea that is "kind of spoiling [his] play" (line 45) is that the dying German is so similar to himself.

But the poem is powerful for another reason as well: the speaker reveals an interesting bit of soldierly ego defense, a coping mechanism to which many have resorted when faced with such internal dissonance. After a reverie of sympathy in the fifth to eighth stanzas, he reverts to bravado and the logic of war. He tells himself "War is war, and he's only a Boche, and we all of us take our chance" (line 47). And, perhaps ironically self-congratulatory for his chosen job as a healer and not a killer, he justifies himself when he admits, "I'm heartily glad I'm not/The man who gave him his broken head, the sniper who fired the shot" (lines 49-50). The speaker's response to the horror he has seen is to deny his responsibility for it, but this denial implies that there is something he feels the need to deny. Even before the turn in the ninth stanza, there are hints at the speaker's internal dissonance. His curse "And confound him, too!" (line 31), which might be commonly directed at an enemy soldier, is here uttered only upon recognition of their common humanity. The speaker curses the German, as if to remind himself that the Boche is a dangerous enemy; but actually the enemy has proved the more ordinary and domestic and familial, and thus he has touched the speaker's sense of guilt. Contact with the dying German has left the speaker nonplussed to say the least, and the poem is about the speaker's exposing his inner conflict and his flailing efforts at justifying or at resolving the inner turmoil of what he has got himself into. This uncomfortable wrestling, this raw revelation of his own struggle, is what makes this poem so compelling.

\section{2. "Strange Meeting" by Wilfred Owen (1918)}

Owen's most poignant example of direct conversation with the enemy is the poem "Strange Meeting" (Owen 1918a), in which the British speaker converses with the German he killed, when both dead men meet in hell. ${ }^{7}$ Sarnowski (2018) has done an admirable job explicating the poem, so I will not go to great length here. The gist of Sarnowski's discussion is that the speaker is humanizing his enemy, as the German speaks of his dreams, virtues, passions, and overall hopelessness-all of which are assumed to be the same as the British Tommy feels. I agree that the common victimhood of the two opponents is a salient theme. But one thing I will add is that it is possible that Owen is here voicing and empowering the enemy not just as a way to give some dignity to the German, but also as a way to expiate his (or his speaker's) guilt, much as Service's speaker tried to resolve his cognitive dissonance in "Only a Boche."

7 Dominic Hibberd (2003) writes: "Among the thousands of poems written during the Great War, there are very few about the poet-soldier meeting his dead victim, fewer still in which the two men talk to each other, and perhaps none except "Strange Meeting" in which the killer stands his ground, accepting the truth of what he has done" (Hibberd 2003, p. 311). 
The irony and absurdity of war and the common humanity of the enemies are all conveyed without need of the last few lines of the poem. But those lines add something important: "I am the enemy you killed, my friend. / I knew you in this dark; for so you frowned / Yesterday through me as you jabbed and killed" (lines 40-42). This revelation is particularly jarring, for with these violent words "jabbed and killed" we are jolted from our reverie. It was not a distant "thump[ing]" gun that killed these men. No, the speaker cannot fully escape his culpability. But he has strategically recalled his personal guilt only at the end, while foregrounding the corporate guilt which he is more ready to acknowledge. $^{8}$

Another coping strategy is that Owen has made some greater meaning from the whole experience, which he shares with us. The German soldier's speech bemoans his inability to tell the truths of war, now that he is dead. He regrets that now "... something had been left / Which must die now. I mean the truth untold" (lines 23-24) and further prophesies, "Now men will go content with what we spoiled, / Or discontent, boil bloody, and be spilled" (lines 26-27). That is, future countrymen will not understand what these speakers have learned. The speech certainly has a mood of sadness and frustration. Those who are best qualified to voice the hell of war are the voiceless dead. But Owen is in fact using the German's would-be speech to tell that very "truth untold," thus deriving at least some meaning from the absurdity, and, importantly, mitigating if not entirely removing his own guilt.

Finally, in this poem, we the readers share in the British soldier-poet's dissonance, for we must ourselves decide what to make of him who on the one hand was a killer but on the other hand is wiser for it. Is the abstracted wisdom worth the very concrete lives of these young men?

\section{3. "That Exploit of Yours" by Ford Madox Ford (1918)}

According to Peter Robinson 2010, Ford wrote this poem "without knowledge of Owen's 'Strange Meeting'" (Robinson 2010, p. 109), but the similarity is remarkable. In this poem (Ford 1918) a first-person speaker finds himself in hell and speaks directly to the enemy who killed him. As in Owen's poem (Owen 1918a), the realm of the dead is depicted as unthreatening rather than terrible. And as with Owen, there is a mood of resignation. But Owen foregrounds the enemy-whom the speaker has killed - and allows him the largest share of lines in the poem. In Ford's poem, the speaker has been killed by his enemy, he only addresses his enemy at the end, the killer's words are imagined but not directly quoted, and it is not clear that the killer is even in the same place or dead at all.

Before addressing his killer, Ford's speaker observes two other soldiers, one English and one German, who are also meeting and who tell each other-and themselves-the same thing, "Exclaim[ing] always in identical tones: / 'I at least have done my duty to Society and the Fatherland!'” (lines 10-11). The speaker mocks their self-important statement by calling it a "cliché" (line 12) and accusing his killer of probably saying the same thing. But the irony goes even further: the two patriots observed by the speaker are actually not noble at all. The British soldier "Was stuck by a pitchfork, / Climbing a wall to steal apples" (lines 3-4), and the German "died from the fall of his horse on some tram-lines/In Dortmund" (lines 6-7). Indeed these two are not even enemy combatants who faced each other; they died in different places under different non-combat circumstances. They are just as dead as other, more noble, victims, however, and they tell themselves what most of us might tell ourselves about the war dead: that their sacrifice was noble and meaningful. The speaker's derision of

8 Hibberd $(1986,2003)$ suggests that Owen's poems of this period might be an effort to deal with guilt or dissonance, but from other sources: "his failure to live up to his own standards" (Hibberd 1986, p. 76) as an officer, and his wrestling with the specter of possibly being a coward. After a stressful battle in which Owen encountered physical and emotional injury-but "may have been helpless with shock" (Ibid., p. 75)—his incoming commanding officer hinted if not directly stated that Owen was a malingerer. Says Hibberd, "Owen would have felt himself disgraced .... It helps to explain his return to the front in 1918 and the heavy weight of guilt that loads his finest writings" (Ibid., p. 77). Hibberd also summarizes Owen's general conflicted-ness about the war: "A soldier had to ignore [Christ's] commandment [of passivity] because Prussian militarism could only be extinguished by military means" (Hibberd 2003, p. 248). 
the "cliché" implies that such a platitude does not ring true. He calls it "strange" (line 12), revealing that he himself is conflicted and unsure how to make sense of his death.

The poet's depictions of the foolish enemies who forever "exclaim" their "cliché" is thematically powerful on its own. But the end-when the speaker confronts his enemy directly-adds something important. We readers may find ourselves conflicted too, since these soldiers are silly while the context of the situation is inherently sad and absurd. But we become even more uncomfortable when, at the end of the poem, Ford has his speaker directly address his own killer:

"For I will bet my hat that you who sent me here to Hell

Are saying the selfsame words at this very moment

Concerning that exploit of yours" (lines 13-15)

Ford's speaker considers that his own death is likely also counted as nothing more than a rousing "exploit" on the part of his enemy. Here again we see some differences from Owen's poem (Owen 1918a) which had the speaker and his enemy share in the wisdom of the grave. In Ford's poem, the speaker is different from his enemy. The enemy is probably saying the same hollow maxims, while the speaker has learned that such statements are foolish. But the poem is inherently frustrating, since-as with Owen's discussion of what might have been - the speaker is in no position to change things beyond uttering what he has observed. Furthermore, having debunked our platitudes, Ford leaves us no axiom to help us make sense of what we have just read.

After all, there is ambiguity in the phrase "you who sent me here to Hell" (line 13). I have been suggesting that this refers to an enemy soldier, but it is hard to ignore the possible double meaning, that we the society, we the readers, are the ones who have condemned him. Regardless of whom he is addressing, we feel the sting when the speaker here calls us out for thinking we understand.

\section{Poems Depicting only the Seeing or Touching of an Enemy}

\section{1. "A Dead Boche" by Robert Graves (1916)}

Robert Graves' poem "A Dead Boche" (Graves 1916) shows a meeting with the enemy. But in this poem, the enemy is dead, and the speaker does not interact with him beyond just observing his decaying body. In the second stanza, the poet shows us the dead man. The last lines run thus:

... a dead Boche; he scowled and stunk

With clothes and face a sodden green,

Big-bellied, spectacled, crop-haired,

Dribbling black blood from nose and beard. (lines 9-12)

The poet's descriptions are unflinching and disgusting, but they are mostly sensory descriptions only, as a photograph would be. That is, though we see the "dribbling black blood" and the "face a sodden green," these do not carry any implication that the man is an enemy or otherwise to be censured. The body could be that of anyone, foe or friend, as the belly, spectacles, hair, blood, nose, and beard could all belong to anyone. The poet does show that the corpse is repugnant, using words like "mess" (line 8), "unclean" (line 8), the mildly disrespectful "Boche" (line 9), and the clause "he scowled and stunk" (line 9), but those are the closest thing to insult or disrespect in the poem, and they only serve to show that the corpse was a horrible thing. In fact, these most insulting words happen early in the description; as the stanza goes on, the connotations become even more mild and neutral, until we are left only with the perfectly neutral words "spectacled," "crop-haired," and "nose and beard." The poet proceeds in this manner to bring us readers with him. Note that the speaker is well aware of his audience, that we are reading his poems looking for "blood and fame" (line 2). The title, and the first reference to the "Boche" in line 9 have set us up to expect something-that there is something particularly important about the dead man's "Boche" identity, his "enemy-ness." But when we finish the description, we find that he is disgusting only because he is dead, and he could have 
been anyone. There is nothing particularly enemy-like or hateful about him. Our partisanship has tempered into general pity. But we shouldn't be surprised; the speaker has told us to expect "A certain cure for lust of blood" (line 6).

This poem shows a change of perspective on the part of the poet-speaker. We could call this a case of dissonance, for the speaker, it seems, had crafted a narrative for himself that no longer serves. (See Canary 1980). He himself probably had wanted to "hear of blood and fame," which would at least go some way toward redeeming the horrible experience of war. But he has come to find that such a telling is not ringing true. He feels guilty that he has told such "songs of War" that might lead his readers to expect the same, and he seeks to warn us against his mistake. He warns us, though, just by showing us a picture, and leaves us to wrestle with our own "blood and fame" narratives as he has had to do. ${ }^{9}$

\section{2. “The Happy Warrior" by Herbert Read (1919)}

Herbert Read's poem "The Happy Warrior" (Read 1919) shows an obvious connection to Wordsworth's poem of a similar name, "Character of the Happy Warrior" (1806) and indeed should be interpreted in light of that connection. Wordsworth asks his reader "Who is the happy warrior? Who is he / That every man in arms should wish to be?" (lines 1-2) and goes on to answer his question by suggesting the happy warrior is a generous and noble spirit, who among other things is described thus:

... if he be called upon to face

Some awful moment to which Heaven has joined

Great issues, good or bad for human kind,

Is happy as a Lover; and attired

With sudden brightness, like a Man inspired;

And, through the heat of conflict, keeps the law

In calmness made, and sees what he foresaw; (Wordsworth 1806, lines 48-54)

In Read's poem, Wordsworth's question is alluded to in the title and in last two lines. But otherwise the poem is starkly different. Read describes the soldier's "painful sobs," (line 1) "strain'd hands," (line 2) "aching jaws," (line 3) "hot parch'd tongue," (line 3) and "Bloody saliva," (line 6). In lines 8-10, the speaker says, "I saw him stab / and stab again / a well-killed Boche." The next two lines are the end: "This is the happy warrior, / this is he..." (lines 11-12).

The poem admits none of the values which would seem to be particularly important to a poet. There is no honor, no nobility - the warrior is sobbing and drooling, probably a victim of shell shock based on his crazed appearance. There is not even consciousness or communication-the warrior is "search[ing] unconsciously" (line 4), he is biting his tongue (line 3), and "He cannot shriek" (line 5). In the place of honor, nobility, consciousness, and communication, there is only savage violence.

Thus the poem stands in sharp contrast to Wordsworth's original thematically. This contrast is underscored by the poet's obvious homage to the original, not just in the direct quotation (title, lines 11-12) but also in the jarring manipulation of the original poem's catalog structure. Wordsworth's poem features lines that are on the whole rather abstract. For example, the selection above contains not a single concrete image, the closest things being the dubious phrases "happy as a Lover" (line 51) and "attired / With sudden brightness" (lines 51-52). Read's poem, though, contains terse, disturbing, concrete images in every line but the last two. In the midst of this perverse third-person catalog,

9 Canary (1980) points out that Graves himself objected to the overly-psychological approach to poetry analyses, insisting that each poem "says exactly what it means" (Graves, quoted in Canary 1980, p. 20). But Canary goes on to point out that Graves also placed "stress on the private source of the conflicts held in tension in the poems" (Canary 1980, p. 23) and that he believed poems stem best from "unforeseen fusion in [the poet's] mind of apparently contradictory emotional ideas" (Graves, quoted in Canary 1980, p. 22). Canary suggests these contradictions include various identities of the poet-speaker, and the act of writing imposes order by reconciling the poet's contradictions (Canary 1980, pp. 22-23). 
the speaker further corrupts Wordsworth's Romantic template by injecting a short first-person account that tells of the warrior's encounter with the enemy: "I saw him stab / and stab again / a well-killed Boche" (lines 8-10). As if the third-person depiction of the warrior is not disturbing enough, the blunt, unadorned first-person account adds to and confirms the truth of the story.

It is unclear if Read himself actually witnessed this behavior, although it is certainly possible. It might not even seem that the speaker himself seems to feel any particular internal dissonance, but I suggest that the matter-of-fact tone shows the speaker's desensitization to such behavior or is an ego defense such as denial or rationalization. Regardless, the poem seems both to express a general dissonance on the part of society as a whole, and to elicit dissonance on the part of all of us readers when we see that the noble young men we send off to fight are rendered helpless and brutish. The reference to the very popular poem of the very British Wordsworth implies that we readers are also supposed to make that connection and to see the difference between the reality on display and the Romantic renderings so prevalent in the culture. And while the sheer contrasts between the Romantic abstraction and the eyewitness concrete description are powerful in themselves, the injection of the stabbing scene - the treatment of the enemy-is important. It is not just the pitiable ruin of a young man that stirs us so; it is the added detail of his crazed, blinded, fruitless brutality that really brings the point home.

\section{3. "Remorse" by Siegfried Sassoon (1918)}

Siegfried Sassoon's "Remorse" (Sassoon 1918) is a poem wherein internal conflict is brought out via an encounter with the enemy, in this case still alive. The poem highlights the guilt and horror of what one does to one's enemies. It is not clear that the character himself touched the Germans or participated quite the same as his comrades did, but he is horrified nonetheless. In this poem the character recollects:

Remembering how he saw those Germans run,

Screaming for mercy among the stumps of trees:

Green-faced, they dodged and darted: there was one

Livid with terror, clutching at his knees ...

Our chaps were sticking 'em like pigs ... 'O hell!'

He thought-'there's things in war one dare not tell'. (lines 7-12)

The poet here conveys the graphic horrors of war. The words are concrete and active: "run" (line 7), "Screaming" (line 8), "dodged and darted" (line 9) "clutching" (line 10), "sticking 'em" (line 11). The tone is appropriately frenetic and terrible: "Screaming for mercy" (line 8), "Livid with terror" (line 10), "'O hell!'" (line 11). And the poet seems to be showing how the terrible violence of war has impacts beyond its stated aims: not only has it hurt the Germans, but it has hurt the environment which is now "swamp"(line 1) and "pit" (line 1) and "stumps" (line 8), and it has hurt the British soldier himself.

The character is obviously moved by what he has witnessed, and we the readers share in the horror. There is a general sympathy toward the German victims, which we the readers also share. But in this poem it is the brutality of the action-brutality displayed by his own men, even, with all the accompanying guilt and cognitive dissonance that brings—-that seems harder to bear than just the horrible ubiquity of death. We the readers share in this brutality too. The speaker ironically tells us exactly that which "one dare not tell," so we now are in on the secret, complicit. But not only do we share the guilt and horror, we watch the character wrestle internally as he decides not to tell what he's seen. Campbell (1999) suggests that the speaker decides to "bottle up the nightmare memories and the sense of guilt that goes with them" (Campbell 1999, p. 179). The brutal action itself is one thing, telling the truth about it is another, and deciding not to tell that truth is yet another. We the readers have experienced all three, because we have watched the poet and his characters do their internal wrestling right in front of us. 


\section{4. "A Night Attack" by Siegfried Sassoon (1916, Published 1970)}

In Sassoon's poem "A Night Attack" (Sassoon 1916), the speaker is safe at an aid or R \& R station behind the lines, and yet he says, "I remember things I'd best forget," (line 2) and goes on to describe a traumatic incident. Stanza two starts with the speaker unable to fully forget the war: "To-night I smell the battle, miles away" (line 9), and in stanza four the speaker fully flashes back to the battle itself when he encountered a dead German soldier. He says:

Then I remembered someone that I'd seen

Dead in a squalid, miserable ditch,

Heedless of toiling feet that trod him down.

He was a Prussian with a decent face,

Young, fresh, and pleasant, so I dare to say.

No doubt he loathed the war and longed for peace,

And cursed our souls because we'd killed his friends. (lines 28-34)

The speaker goes on to imagine what the German was probably doing at the time of his death-likely watching his friends shoveling and otherwise ignoring the British onslaught as best he could, (in the same way the British would have acted on their side). Then in stanza 6 the speaker's identification with the dead Prussian becomes even more pronounced: "Then the damned English loomed in scrambling haste / Out of the dark and struggled through the wire" (lines 46-47). Here the British speaker is able so to see from the German perspective that he can even curse his own side, not just assuming what the man must have thought as in line 34, but actually speaking from the German point-of-view. The last lines of the poem describe the body of the enemy:

I found him there

In the gray morning when the place was held.

His face was in the mud; one arm flung out

As when he crumpled up; his sturdy legs

Were bent beneath his trunk; heels to the sky. (lines 53-57)

The "decent face, / Young, fresh, and pleasant" is now "in the mud;" his "sturdy legs" bent awkwardly, or even in a position of kneeling and abject humiliation. The implication is that it is not just the horror of encountering a dead man that has rendered our speaker so emotionally ragged, but that it is the guilt and immorality of witnessing the ruin of a would-be decent fellow person. The speaker has said that he is remembering "things [he'd] best forget" (line 2); his ego no doubt demands that he should forget or try to forget, but he is unsuccessful in this attempt. Rather, his answer to the inner conflict between his duty to fight for England and his revulsion at how he has ruined another man is to entertain a "reassessment of the patriotic ethic" (Campbell 1999, p. 111). ${ }^{10}$

\section{5. "Enemies" by Siegfried Sassoon (1917)}

A final poem of this type is Sassoon's poem "Enemies" (Sassoon 1917a) in which the speaker mentions the "hulking Germans that I shot" trying to protect a comrade. The setting of the vision is "some queer sunless place / Where Armageddon ends" (line 1-2), which suggests the same realm as Owen would later describe in his "Strange Meeting" (Owen 1918a) and Ford in "That Exploit of Yours" (Ford 1918). The place is "queer" and "sunless" but hardly infernal. Indeed the only thing described as "hot" is the speaker's own "brooding rage" (line 6).

The second stanza shows the friend and the Germans together in the realm of the dead:

10 That the poet is conflicted might also reflected by Sassoon's refusal to publish the poem, likely concerned that "its embryonic pacifist sentiments and the Prussian soldier's view of "damned English" might be altogether too contentious" (Campbell 1999, p. 110). 
He stared at them, half-wondering; and then

They told him how I'd killed them for his sakeThose patient, stupid, sullen ghosts of men;

And still there seemed no answer he could make.

At last he turned and smiled. One took his hand

Because his face could make them understand.

While the speaker seems to have seen the Germans die, there is no gory detail about their bodies. Indeed these Germans are now ghosts who understand their fate and gently gather and take the hand of the dead English friend. There is no horror here, indeed not even much of a sense of guilt. Taken together with the setting, the words "untroubled" (line 4), "patient," (line 9) and "smiled," (line 11) and the clauses "One took his hand," (line 11) and "his face could make them understand" (line 12), establish a tone that is resigned at worst, perhaps even beatific.

The speaker knows he bears some responsibility. He knows he is the one who shot the Germans (line 5) and that he did so in a heated rage (line 6). But this guilt is not nearly as salient as the overall mood of quietness and acceptance. The speaker is quite likely justifying himself: the killing of the enemies is not so bad because they are now in a better place among a brotherhood of the dead. This could be another case of turning a horror into a beauty, as we will see Owen do in "Has Your Soul Sipped?" (Owen 1918b). The situation must have been intense and dire indeed: watching his friend in danger and dying, being unable to help except from a distance, rendering his help by bringing gross death to the friend's assailants, only to have his friend die after all. On recollecting, the speaker's horror is softened into something of a dream to convince himself that he is an agent of something bigger than himself. This dream makes his own guilt less salient, but that comes at the cost of self-deception; he must construct an alternative to the waste he has seen. The dead thus are said to share something beautiful which the rest of us have yet to achieve. The poem is poignant, and its power comes not just from the paradoxical rendering of a horrible scene into a beautiful one, but also from our sense that we have just watched the poet-speaker wrestle with those demons. We are as powerless to stop his self-deception as he was to stop his friend's death.

\section{Poems Depicting a Dead Soldier Whose Identity as an Enemy is Uncertain}

\section{1. "The Rear-Guard" by Siegfried Sassoon (1917)}

Sassoon's "The Rear-Guard" (Sassoon 1917b) may be about direct contact with an enemy soldier. In this piece, the soldier's tour of a fetid dugout becomes dramatically hellish when the soldier discovers the man he's been trying to awaken is in fact dead:

Savage, he kicked a soft, unanswering heap,

And flashed his beam across the livid face

Terribly glaring up, whose eyes yet wore

Agony dying hard ten days before;

And fists of fingers clutched a blackening wound". (lines 14-18)

The character is horrified and runs out of the dugout, "Unloading hell behind him step by step" (line 25).

"The Rear-Guard" is less obviously about an enemy. In fact, no mention is made of the nationality of either the dugout or the dead man. Tim Kendall's note on this poem indicates that there was an actual incident that precipitated this poem, when either Sassoon or his Company Commander asked directions of a dead man, and in that incident the deceased was German (Kendall 2013, p. 254). The poem's title and the soldier's confusion would seem to imply that the soldier is in the enemy's trench, so taken together we may infer that the dead man is German.

But while this is a harrowing brush with a dead enemy soldier, there is no reflection, no lesson learned, no voice given to the dead. The dead man is horrible, but only because he is dead; shaking a 
dead Englishman would likely have yielded the same response. This poem certainly is a powerful poem, but its theme is the overall hell of war rather than a particular lesson learned from encountering the enemy.

Nevertheless, the act of encountering the dead man has been impactful. The soldier has been shocked or awakened by and to the horrors around him. The poem is told in third-person, unlike all but one of the other examples; presumably the speaker (whether the same as the soldier or not) is creating distance, telling the poem in third person as a way of easing his troubled mind. The act of writing the poem itself could also be considered an act of "Unloading hell behind him" (line 25), and in fact Hipp (2005) has rendered a very good reading of this poem in these terms. Hipp points out that the character in the poem flees, "Climb[ing] through darkness to the twilight air" (line 24), ironically considering the "twilight" of the violent battlefield to be "rosy" (line 7), better than the "unwholesome air" (line 3) of the safer trench which to him is hell (Hipp 2005, pp. 158-59). Hipp suggests this poetic irony is reflective of Sassoon's wounded and conflicted state, wherein "returning to the war was the only means of achieving inner peace" (Hipp 2005, p. 159; see also Campbell 1999, p. 142).

\section{2. "Has Your Soul Sipped?" by Wilfred Owen (1918)}

Another Wilfred Owen piece that might involve contact with the enemy is "Has Your Soul Sipped?" (Owen 1918b) which mentions a dead boy. It is unclear if this boy is an enemy, a fellow British soldier, purely a poetic construction, or a composite of wounded and dying youth of both sides. Possibly the poem could imply that Owen himself had participated in the killing of an enemy at close range, as is likely based on the stories of his gallantry that won him the Military Cross. ${ }^{11}$ Or it could even be that he had seen or participated in the murder of a prisoner (presumably German, but possibly British)—although it should be noted that this is a conjecture for which neither Hibberd nor other biographers give any indication. Alternatively, it may be about a young man under Owen's command, since the metaphor shows a "martyr / Smiling at God," (lines 33-34) and Owen says, "To me was that smile," (line 35) implying an analogous relationship. This is consistent with Hibberd's statement about Owen's anxiety for his perceived failings as an officer (Hibberd 1986, pp. 71-78). I discuss the poem here because it may be about a close encounter with the enemy-though admittedly it may be about some other poor lad. If it is about a fellow British soldier, it still reflects the cognitive dissonance we have seen in the other works under discussion. If it is in fact about an enemy, the argument is so much the stronger.

In the poem, the speaker discusses a strange beauty he has found in war. He asks, "Has your soul sipped / Of the sweetness of all sweets?" (lines 1-2) and, starting in the second stanza, he provides his own answer:

I have been witness

Of a strange sweetness,

All fancy surpassing

Past all supposing.

From here, the poet describes this "strange sweetness" as "sweeter than nocturnes / Of the wild nightingale" (lines 15-16) and "sweeter than odours / Of lifting leaves" (lines 19-20). Then the poem gradually turns away from nature imagery and towards words more associated with war, as the sweetness is now said to be "Sweeter than death" (line 23) "Or the proud wound / The victor wears" (lines 27-28). Finally, the speaker says the sweetness is sweeter than all these things ...

11 Hibberd (2003) includes the text of the citation accompanying Owen's Military Cross: “On the Company Commander becoming a casualty, he assumed command and shewed fine leadership and resisted a heavy counter attack. He personally manipulated a captured enemy M.G. from an isolated position and inflicted considerable losses on the enemy. / Throughout he behaved most gallantly" (p. 376).

Interestingly, Owen's brother Harold has a different version which paints Wilfred as less violent; it reads "He personally captured an enemy Machine Gun in an isolated position and took a number of prisoners." Hibberd discusses the efforts of Harold and other writers to protect Wilfred's reputation after his death (ibid., pp. 367-76). 
Or the sweet murder

After long guard

Unto the martyr

Smiling at God;

To me was that smile,

Faint as a wan, worn myth,

Faint and exceeding small,

On a boy's murdered mouth.

The poem exhibits the use of pararhyme or "consonantal rhyme" as Lewis calls it (Owen 1964, p. 113), which strikes me as creating a haunting and suspenseful mood. The pararhyme leads to a pervasive sense that the clusters of images in the poem are less than solidly connected, that the poet-speaker is knowingly linking things that do not quite go together as neatly as he implies.

This poem is troubling, partly because the horrible is so close to-even identical to- the sweet. We can perhaps appreciate that there must be some beauty in the relief that an imprisoned martyr must feel when long-anticipated death finally comes, but it is less clear how the death of a murdered boy fits the same beauty. Regardless of the incident itself that gave rise to the poem, Owen's point seems to be that in war there is a reordering of values, an acceptance of the surreal, and a desire to affix meaning to the meaningless. Owen is dealing with cognitive dissonance by celebrating an ugliness as if it were beauty.

George Johnson (2010) suggests that part of Owen's dissonance has to do with his homosexuality, and Johnson interprets "Has Your Soul Sipped" in this light, suggesting that the crux is that the speaker of the poem is enraptured with the smile of the dead boy. Borrowing from and extrapolating Johnson's reading, I suggest that the somewhat surprising ending to the poem-“'All his life's sweetness / Bled into a smile" (lines 45-46) -is multi-layered and ironic in many ways: not only is the speaker daringly expressing his ironic attraction to that which is dead, finding beauty in the hell around him, but he also is expressing another great secret: that the boy's mouth itself is what is attractive. At another level, the paradox of finding beauty amid the war might be rather starkly poignant, but ultimately it could be acceptable to readers as something raw and authentic from a young man struggling to understand the hell he has been forced into; but the paradox of the bard's homoerotic attraction to the boy would likely not be acceptable at all, and yet it may be the more deeply-seeded. Finally, it is noteworthy that both conflicts in a sense are forced onto him: he is a victim of the war, of the society that caused the war, of his desires, and of the society of readers who want to hear what he has to say and yet simultaneously do not. I do not doubt that such socio-sexual conflicts as Johnson describes are indeed part of Owen's motivation. Regardless, such conflicts would surely augment the already-tangible cognitive dissonance any soldier would face.

\section{3. "Mental Cases" by Wilfred Owen (1918)}

"Mental Cases" is another poem of Owen's that describes encountering dead soldiers (Owen 1918c). In this case, again, it is unclear if the dead are enemies or comrades. This anonymity is probably part of Owen's point, though. The "Multitudinous murders they once witnessed" (line 12), the "blood from lungs that had loved laughter" (line 14), the "shatter of flying muscles" (line 16), and "Carnage incomparable" (line17) are witnessed just the same, whether done to enemies' bodies or to comrades'. Perhaps that is why Owen does not specify the victims. Rather, the horror is shared, by those who died and by those who killed, by those who went insane and by those who did not, by all of us.

The poem opens with the question "Who are these?" (line 1) and describes the mental cases as "purgatorial shadows" (line 2), "Baring teeth that leer like skulls' teeth wicked" (line 4). At the end of the first stanza the speaker asks again: "Surely we have perished / Sleeping, and walk hell; but who these hellish?" (line 8-9). The speaker is establishing a contrast here between "we" and "they," stating that "we" are among those who "walk hell" - thus, probably soldiers. But the distinction between "we" and "they" is cleverly undercut later when the word "us" is used in a more inclusive and poignant sense.

In the last few lines, the mental cases are: 
... plucking at each other;

Picking at the rope-knouts of their scourging;

Snatching after us who smote them, brother,

Pawing us who dealt them war and madness. (lines 25-28)

The trauma, the horror, the understandable collapse into insanity which these men face is the fault of "us," not them. Combatants and non-combatants alike, we are all guilty of their ruin.

But there is a psychological element too, across several layers. The speaker refers to the mental cases as "them," creating some distance between them and himself (and us). But it is clear that he sympathizes with them, that he understands and sides with them, even against "us" and himself. This identification with the stricken but also as a commentator could be a means of ego defense as well. Clearly, the "mental cases" themselves are not to blame, but what allows the speaker to have escaped their fate? Blaming "us who dealt them war and madness" could be Owen spreading the blame, which is much too heavy for a single soul. Arthur Lane (1972) says, "Owen is unambiguous in assigning the greater guilt, the guilt of complicity in evil, to the reader and to himself" (Lane 1972, p. 155). Indeed Owen was an officer, and thus he shares some of the responsibility of "dealing" the madness, but he shares the blame with all officers, and with those senior statesmen, and with his entire nation, and with us the readers. ${ }^{12}$

\section{Discussion and Conclusions}

We know the poets themselves did experience internal dissonance. Silkin (1996) discusses in a philosophical way the conflicting roles of the poet who is not just a mouthpiece but also an artist, and he illustrates this conflict with quotes from one of Owen's letters: "Thus you see how pure Christianity will not fit in with pure patriotism,'" (p. 21) and again, "'And am I not myself a conscientious objector with a very seared conscience?'" (p. 21). These dissonances-Christian versus patriot, conscientious objector versus confirmed killer, even poet versus participant-provide the power for much of the greatest poetry from Owen and his fellow soldier-poets. Indeed, Silkin suggests the stark dissonance has actually contributed to the poets' output: "This is the nub of Owen's poetry, from which the compassion flows. Compassion is the blood that issues from the wound, and the wound is caused by our soldiering" (p. 21).

Owen was torn with such internal dissonance. Sassoon was Mad Jack the war hero but also an outspoken critic of the war, not just through his famous renunciation, but also through his satiric and barbed poems obviously intended to strike a nerve. Graves's interposition on Sassoon's behalf-arranging for Siegfreid to be sent to Craiglockhart instead of being cashiered or worse-was also an act that would have elicited dissonance, since Graves found himself having to work within the objectionable system in order to save his friend from that same system. Robert Service found himself doing his bit, hoping his non-combatant role would spare his conscience perhaps, but nonetheless seared by what he saw.

Since the dissonance was such a salient experience to all of these poets, and so central to their very themes, they likely sought to express that as many ways as they could. Poems about the enemy are one effective means for that expression. We have considered poems in which the speaker directly converses with an enemy, poems in which the speaker only sees or touches a dead enemy, and poems which could be about an enemy but do not make it clear. In all of these, the idea of cognitive dissonance has yielded meaningful readings. I suggest this is because the poets are allowing us to observe their

12 Lane (1972) also points out other inner conflict revealed in the poem. He points out what others have noted-that there is a borrowing from Dante and from the book of Revelation (See also Hipp 2005, p. 72; Kendall 2013, p. 279) -but also notes that "Though the poem's images may echo traditional religious conceptions, the world within which it moves is unremittingly secular; the tension between the two factors is an indication of Owen's tortured speculation about a hell which men have designed, and in which men are condemned to suffer" (Lane 1972, p. 154). 
internal dissonance, at no time more prominent than when in contact with the enemy, since such personal exposure elicits powerful reactions in us as readers.

Of course, beyond these three types of enemy-encounter poems, there are other powerful poems from the Great War which do not involve contact with the enemy at all. While we have seen how these enemy-encounter poems are conducive to expressing the poet's cognitive dissonance, these poems are the not only ones that convey inner turmoil, to be sure. However, I submit these poems about the enemy convey the dissonance in particularly powerful ways.

Interestingly, I am not sure that the poems featuring direct intimate interaction were necessarily the most moving type of the three. All three of my categories seemed capable of showing internal dissonance and of eliciting the same in the reader, even those that were unclear as to the dead man's identity. Perhaps a key is that, whether in an extended conversation or in a very brief horrific glimpse, the encounter with the dead (especially a dead enemy) does bring the two fighters into close contact. The power of this contact is consistent with Sarnowski's idea that distance matters (2018). Indeed, it may be that dissonance and distance are loci of power, and exposure to the dead —of either side-is another. This is a topic that would be worth exploring in future research.

Further research would also do well to consider the differences between poems by combatants like Graves, Sassoon, and Owen, and poems by non-combatants like Service, John McCrae, May Wedderburn Canaan, and Mary Borden. After all, of all the poems considered for this paper, it was a poem by Robert Service of the ambulance corps that was the only one to portray direct physical contact with a living enemy soldier, and with profound results. This too seems to be rich ground for further exploration.

Indeed, the poets are full of the wisdom of war-the first principle of which is that we and our enemies share a common susceptibility to death. But a darker wisdom might be that even gaining this understanding often involves trauma to the soul. We as readers cannot, perhaps, experience the poets' turmoil as our own, not fully. But we can learn vicariously what they had to learn traumatically. Thus, on some occasions, the poets let us see their own internal dissonance, and their vulnerability and honesty are what gives their poems such power.

Funding: This research received no external funding.

Conflicts of Interest: The author declares no conflict of interest.

\section{References}

Campbell, Patrick. 1999. Siegfried Sassoon: A Study of the War Poetry. Jefferson: McFarland and Co.

Canary, Robert H. 1980. The Lyric Poet. In Robert Graves. Twayne's English Authors Series 279. Boston: Twayne Publishers, pp. 15-29. Available online: http:/ /link.galegroup.com/apps/doc/CX1897700011/GVRL?u= anna82201\&sid=GVRL\&xid=93a962f5 (accessed on 25 January 2019).

Elliot, Andrew J., and Patricia G. Devine. 1994. On the Motivational Nature of Cognitive Dissonance: Dissonance as Psychological Discomfort. Journal of Personality and Social Psychology 67: 382-94. [CrossRef]

Festinger, Leon. 1957. A Theory of Cognitive Dissonance. Stanford: Stanford University Press.

Festinger, Leon, and James M. Carlsmith. 1959. Cognitive Consequences of Forced Compliance. The Journal of Abnormal and Social Psychology 58: 203. [CrossRef]

Ford, Ford Madox. 1918. That Exploit of Yours. In The Penguin Book of First World War Poetry. Edited by Jon Silkin. London: Penguin.

Graves, Robert. 1916. A Dead Boche. In Poetry of the First World War: An Anthology. Edited by Tim Kendall. Oxford: Oxford World Classics.

Hardy, Thomas. 1915. The Pity of It. In Poetry of the First World War: An Anthology. Edited by Tim Kendall. Oxford: Oxford World Classics.

Hibberd, Dominic. 1986. Owen the Poet. Athens: University of Georgia Press, pp. 71-82.

Hibberd, Dominic. 2003. Wilfred Owen: A New Biography. Chicago: Ivan R. Dee, pp. 243-304.

Hipp, Daniel. 2005. The Poetry of Shell Shock: Wartime Trauma and Healing in Wilfred Owen, Ivor Gurney, and Siegfried Sassoon. Jefferson: McFarland and Co. 
Johnson, George M. 2010. 'Purgatorial Passions': 'The Ghost' (a.k.a. Wilfred Owen) in Owen's Poetry. The Midwest Quarterly 58: 152. Available online: http://link.galegroup.com/apps/doc/A217772403/ITOF?u=anna82201\& sid=ITOF\&xid=88c15348 (accessed on 8 January 2019).

Kendall, Tim. 2013. Poetry of the First World War: An Anthology. Oxford: Oxford World Classics.

Kipling, Rudyard. 1914. For All We Have and Are. In Poetry of the First World War: An Anthology. Edited by Tim Kendall. Oxford: Oxford World Classics.

Kipling, Rudyard. 1918. Justice. In Poetry of the First World War: An Anthology. Edited by Tim Kendall. Oxford: Oxford World Classics.

Klug, Wayne, Anne O'Dwyer, Deirdre Barry, Leah Dillard, Haili Polo-Neil, and Megan Warriner. 2011. The Burden of Combat: Cognitive Dissonance in Iraq War Veterans. In Treating Young Veterans: Promoting Resilience through Practice and Advocacy. Edited by Diann Cameron Kelly, Sydney Howe-Barksdale and David Gitelson. New York: Springer Publishing Co., pp. 33-79.

Krause, Merton S. 1972. An Analysis of Festinger's Cognitive Dissonance Theory. Philosophy of Science 39: 32-50. [CrossRef]

Lane, Arthur E. 1972. An Adequate Response: The War Poetry of Wilfred Owen and Siegfried Sassoon. Detroit: Wayne State University Press.

MacCurdy, John. 1918. War Neuroses. In The Poetry of Shell Shock: Wartime Trauma and Healing in Wilfred Owen, Ivor Gurney, and Siegfried Sassoon. Jefferson: McFarland and Co.

McLeod, Saul A. 2018. Cognitive Dissonance. Available online: https://www.simplypsychology.org/cognitivedissonance.html (accessed on 9 January 2019).

Owen, Wilfred. 1918a. Strange Meeting. In Poetry of the First World War: An Anthology. Edited by Tim Kendall. Oxford: Oxford World Classics.

Owen, Wilfred. 1918b. Has Your Soul Sipped. In The Collected Poems of Wilfred Owen. Edited by C. Day Lewis. New York: New Directions.

Owen, Wilfred. 1918c. Mental Cases. In Poetry of the First World War: An Anthology. Edited by Tim Kendall. Oxford: Oxford World Classics.

Owen, Wilfred. 1964. The Collected Poems of Wilfred Owen. Edited by C. Day Lewis. New York: New Directions.

Ramazani, Jahan. 2016. 'Cosmopolitan Sympathies': Poetry of the First Global War. Modernism/Modernity 23: 855-74. [CrossRef]

Read, Herbert. 1919. The Happy Warrior. In The Penguin Book of First World War Poetry. Edited by Jon Silkin. London: Penguin.

Robinson, Peter. 2010. 'Written at least as well as prose': Ford, Pound, and Poetry. In Ford Madox Ford: Modernist Magazines and Editing. Edited by Jason Harding. International Ford Madox Ford Studies 9. General editor Max Saunders. The Ford Madox Ford Society. New York: Rodopi, pp. 99-114. Available online: https://epdf. tips/ford-madox-ford-modernist-magazines-and-editing-international-ford-madox-ford-st.html (accessed on 11 February 2019).

Sarnowski, Michael. 2018. Enemy Encounters in the War Poetry of Wilfred Owen, Keith Douglas, and Randall Jarrell. Humanities 7: 89. [CrossRef]

Sassoon, Siegfried. 1916. A Night Attack. In Poetry of the First World War: An Anthology. Edited by Tim Kendall. Oxford: Oxford World Classics.

Sassoon, Siegfried. 1917a. Enemies. In The War Poems of Siegfried Sassoon. Arranged and Introduced by Rupert Hart-Davis. London: Faber and Faber.

Sassoon, Siegfried. 1917b. The Rear Guard. In Poetry of the First World War: An Anthology. Edited by Tim Kendall. Oxford: Oxford World Classics.

Sassoon, Siegfried. 1918. Remorse. In The War Poems of Siegfried Sassoon. Arranged and Introduced by Rupert Hart-Davis. London: Faber and Faber.

Sassoon, Siegfried. 1983. The War Poems of Siegfried Sassoon. Arranged and Introduced by Rupert Hart-Davis. London: Faber and Faber.

Service, Robert. 1916. Only a Boche. In Poetry of the First World War: An Anthology. Edited by Tim Kendall. Oxford: Oxford World Classics.

Silkin, Jon. 1996. Introduction. In The Penguin Book of First World War Poetry. Edited by Jon Silkin. London: Penguin, pp. 16-77.

Stallworthy, Jon. 1974. Wilfred Owen. London: Oxford University Press, London: Chatto \& Windus. 
Ward, Candace, ed. 1997. World War One British Poets: Brooke, Owen, Sassoon, Rosenberg and Others. Mineola: Dover. Wordsworth, William. 1806. Character of the Happy Warrior. In The Poetical Works of William Wordsworth. Edited by William Knight. London: MacMillan, Vol. IV, Available online: http:/ /www.gutenberg.org/files/32459/ 32459-h/32459-.htm\#CHARACTER_OF_THE_HAPPY_WARRIOR (accessed on 11 February 2019). 